\title{
Functional analysis reveals no transcriptional role for the glucocorticoid receptor $\beta$-isoform in zebrafish
}

\author{
Antonia Chatzopoulou, Peter J. Schoonheim, Vincenzo Torraca, Annemarie H. Meijer, \\ Herman P. Spaink, Marcel J.M. Schaaf* \\ Institute of Biology (IBL), Leiden University, Leiden, The Netherlands
}

\section{A R T I C L E I N F O}

\section{Article history:}

Received 12 October 2016

Received in revised form

30 January 2017

Accepted 23 February 2017

Available online 24 February 2017

\section{Keywords:}

Glucocorticoid receptor

Beta-isoform

Zebrafish

Corticosteroid

Microarray

Transcriptome analysis

\begin{abstract}
A B S T R A C T
In humans, two splice variants of the glucocorticoid receptor (GR) exist: the canonical $\alpha$-isoform, and the $\beta$-isoform, which has been shown to have a dominant-negative effect on hGR $\alpha$. Previously, we have established the occurrence of a GR $\beta$-isoform in zebrafish, and in the present study we have investigated the functional role of the zebrafish GR $\beta$ (zGR $\beta$ ). Reporter assays in COS- 1 cells demonstrated a dominantnegative effect of zGR $\beta$ but no such effect was observed in zebrafish PAC2 cells using induction of the fk506 binding protein 5 ( $f k b p 5)$ gene as readout. Subsequently, we generated a transgenic fish line with inducible expression of zGR $\beta$. Transcriptome analysis suggested transcriptional regulation of genes by $z G R \beta$ in this line, but further validation failed to confirm this role. Based on these results, its low expression level and its poor evolutionary conservation, we suggest that the zebrafish GR $\beta$-isoform does not have a functional role in transcriptional regulation.
\end{abstract}

(C) 2017 Elsevier B.V. All rights reserved.

\section{Introduction}

The glucocorticoid receptor (GR) is expressed throughout the human body and regulates a wide variety of biological processes, like our metabolism, growth, reproduction, vascular tone, bone formation, immune response and brain function (Chrousos and Kino, 2005; de Kloet et al., 2005; Heitzer et al., 2007; Revollo and Cidlowski, 2009; Sapolsky et al., 2000; Schoneveld et al., 2004). The GR is activated upon binding to glucocorticoid (GC) ligands, and acts as a transcription factor, orchestrating gene expression via DNA-binding-dependent and -independent mechanisms (Beato and Klug, 2000, Buckingham, 2006; De Bosscher and Haegeman, 2009, Heitzer et al., 2007; Nicolaides et al., 2010; Schoneveld et al., 2004; van der Laan and Meijer, 2008). Cloning of the human GR gene revealed the occurrence of two splice variants, named as hGR $\alpha$ and hGR $\beta$, which derive from alternative usage of an acceptor splice site within the last coding exon (exon 9, see Suppl. Fig.1) (Encio and Detera-Wadleigh, 1991; Hollenberg et al., 1985). The GR $\alpha$-isoform ( 777 amino acids) is able to interact with GCs, and represents the canonical receptor. The hGR $\beta$-isoform (742

\footnotetext{
* Corresponding author. Einsteinweg 55, 2333CC Leiden, The Netherlands.

E-mail address: m.j.m.schaaf@biology.leidenuniv.nl (M.J.M. Schaaf).
}

amino acids) has a shorter LBD with a unique C-terminal 15 amino acid sequence, which renders it unable to respond to GCs (Encio and Detera-Wadleigh, 1991; Hollenberg et al., 1985; Kino et al., 2009a,b).

Almost ten years after the discovery of hGR $\beta$, it was shown using in vitro reporter assays that this isoform had a pronounced dominant-negative inhibitory effect on hGR $\alpha$ 's transcriptional properties on GRE-containing promoters (Bamberger et al., 1995; Oakley et al., 1996, 1999). Moreover, hGR $\alpha$-mediated repression of $\mathrm{NF}-\kappa \mathrm{B}$ activity in in vitro reporter assays was also reported to be inhibited by hGR $\beta$ (Oakley et al., 1999). These findings were soon coupled to clinical data demonstrating a positive correlation between high expression levels of the $\beta$-isoform and GC resistance of patients suffering from immune-related disorders, like asthma (Christodoulopoulos et al., 2000; Goleva et al., 2006; Hamid et al., 1999; Hamilos et al., 2001; Leung et al., 1997; Sousa et al., 2000), ulcerative colitis (Fujishima et al., 2009; Orii et al., 2002; Zhang et al., 2005), leukemia (Koga et al., 2005; Longui et al., 2000; Shahidi et al., 1999) and rheumatoid arthritis (Derijk et al., 2001; Goecke and Guerrero, 2006). Further cell-based research has supported an inhibitory role for hGR $\beta$ on both hGR $\alpha$-induced activation and repression of endogenous genes (MKP-1, myocilin, fibronectin, TNF $\alpha$ and IL6 (Goleva et al., 2006; Li, 2006; Zhang, 2005)), as well as on hGR $\alpha$-mediated regulation of cell death, proliferation and 
phagocytosis (Hauk et al., 2002; Strickland et al., 2001; Zhang et al., 2007). Moreover, recent data support the notion that hGR $\beta$ can have its own intrinsic transcriptional activity. Overexpression of zGR $\beta$ has been demonstrated to attenuate NF- $\kappa B$ and AP- 1 induction of luciferase reporter constructs (Gougat et al., 2002), as well as GATA3-mediated activation of IL5 and IL13 promoters of luciferase genes (Kelly et al., 2008). Additionally, transcriptome analyses of cultured cells showed that hGR $\beta$ can direct gene transcription independently of hGR $\alpha$ activation (Kino et al., 2009a,b; Lewis-Tuffin et al., 2007). In a recent study, overexpression of hGR $\beta$ in the liver of mice showed both GR $\alpha$-dependent and -independent regulation of gene expression by hGR $\beta$ (He et al., 2016).

Despite the available data described above, the physiological relevance of hGR $\beta$ is still under debate. First, in many studies the dominant-negative role of hGR $\beta$ on hGR $\alpha$ 's transcriptional properties could not be confirmed (Bamberger et al., 1997; Brogan et al., 1999; Carlstedt-Duke, 1999; Gougat et al., 2002; Hecht et al., 1997; Kelly et al., 2008; Kim et al., 2009; Taniguchi et al., 2010). Second, hGR $\beta$ 's expression levels are significantly lower compared to those of hGR $\alpha$ (Bamberger et al., 1995; de Castro et al., 1996; Oakley et al., 1996, 1997; Pujols et al., 2002; Strickland et al., 2001). This raises doubts about its in-vivo dominant-negative effect, since in most studies this required transfection of a 10-M excess of hGR $\beta$ expression vector compared to hGR $\alpha$ (Bamberger et al., 1995; Oakley et al., 1996, 1999). Third, the evolutionary conservation appears to be poor. Previously, we showed that the GR $\beta$ protein sequence is only conserved between primates, and that the gene organization required for GR $\beta$ expression is present in a limited group of placental mammals (Schaaf et al., 2008). For example, rodents, cats, dogs and hedgehogs contain a mutation in the splice acceptor site required for GR $\beta$ expression (Otto et al., 1997; Schaaf et al., 2008). As a result, until recently no animal model was available for functional studies on GR $\beta$.

Remarkably, several years ago we discovered the occurrence of a GR $\beta$-isoform in zebrafish (Schaaf et al., 2008). Like its human equivalent, the zebrafish GR $\beta$-isoform differs from the $\alpha$-isoform at the C-terminus and diverges from the GR $\alpha$ sequence at the same point as the human GR $\beta$. Both the human and zebrafish GR $\beta$-isoforms exhibit the same predominantly nuclear localization, and zGR $\beta$ also acts as a dominant-negative inhibitor of zGR $\alpha$-mediated transactivation in in vitro reporter assays (Schaaf et al., 2008). However, differences exist between these GR $\beta$-isoforms, which demonstrates that they have evolved independently. First, the GR $\beta$ specific C-terminal sequences are very different between zebrafish and human GR $\beta$ (Schaaf et al., 2008; Yudt et al., 2003). Second, in the human GR gene the GR $\beta$-specific sequence is located in exon 9, whereas in the zebrafish GR gene it is found in the intronic sequence immediately downstream of exon 8 (Suppl. Fig.1). Thus, human and zebrafish GR $\beta$ mRNA are generated using different alternative splicing mechanisms (exon replacement and intron retention, respectively (van der Vaart and Schaaf, 2009)). A few years after our discovery of the zebrafish GR $\beta$, a GR $\beta$-isoform generated by intron retention was observed in mice as well, and this isoform appears to play a role in metabolic regulation (Hinds et al., 2010).

The scope of this study was to investigate the role of zGR $\beta$ in gene transcription either as a dominant-negative inhibitor of zGR $\alpha$ or as a transcription factor independent of zGR $\alpha$. We have utilized both in vitro and in vivo approaches. While a dominant-negative effect of zGR $\beta$ was observed in reporter assays in cultured cells, our data did not reveal any dominant-negative activity of zGR $\beta$ on endogenous genes in either cultured cells or zebrafish larvae. Furthermore, we found no convincing evidence for an intrinsic transcriptional activity of zGR $\beta$.

\section{Materials and methods}

\subsection{Cell cultures}

COS- 1 cells were cultured in DMEM (Invitrogen), supplemented with $10 \%$ fetal bovine serum (Invitrogen) and $1 \%$ penicillin and streptomycin (Invitrogen). Cells were grown at $37{ }^{\circ} \mathrm{C}$ and $5 \% \mathrm{CO} 2$. PAC2 zebrafish cells were cultured in Leibovitz's medium (Invitrogen), supplemented with 15\% fetal bovine serum (Invitrogen) and $1 \%$ penicillin and streptomycin (Invitrogen). Cells were grown at $28{ }^{\circ} \mathrm{C}$.

\subsection{Luciferase reporter assays in COS-1 cells}

COS- 1 cells were seeded into 24 -well plates $\left(3 \times 10^{4}\right.$ cells/well). Transfection was performed $24 \mathrm{~h}$ later using the TransIT ${ }^{\mathbb{R}}-\mathrm{COS}$ Transfection Kit (Mirus Bio) according to the manufacturer's instructions. MMTV:luciferase reporter construct (200 ng) was transfected, with a range of PCS $+\mathrm{zGR} \alpha$ plasmid concentrations (1-300 ng) and/or $100 \mathrm{ng}$ pCS2 $+\mathrm{zGR} \beta$ expression vector (Schaaf et al., 2008), together with 2 ng pCMV:renilla (Promega). In a second set of experiments, cells were transfected with $50 \mathrm{ng}$ of a $\kappa B$ :luciferase reporter construct (Stratagene) and $50 \mathrm{ng}$ of a human p65 expression vector (pCMV4-p65 (Ruben et al., 1991)), together with a range of $\mathrm{pCS} 2+\mathrm{zGR} \alpha$ concentrations $(0-1000 \mathrm{ng}$ ) in the presence and absence of $100 \mathrm{ng} \mathrm{pCS} 2+\mathrm{zGR} \beta$. The total amount of transfected DNA was always kept equal among groups by transfecting empty pCS2+ vector. Twenty-four hours after transfection, cells were treated with $100 \mathrm{nM}$ dexamethasone (Sigma) and $24 \mathrm{~h}$ later, they were assayed for luciferase activity using the DualLuciferase $^{\circledR}$ Reporter Assay System (Promega). Bioluminescence was detected using a Wallac 1450 MicroBeta Luminometer. For each sample, the luciferase activity was normalized to the renilla activity. Per sample, measurements were performed in duplicate, and data shown are averages \pm s. e.m. of three experiments.

\subsection{Gene expression analysis using the $P A C 2-z G R \beta$ cell line}

The pCS2 $+\mathrm{zGR} \beta$ plasmid (Schaaf et al., 2008) and a neomycin resistance plasmid were transfected into PAC2 zebrafish cells using the Amaxa ${ }^{\circledR}$ Cell line Nucleofector kit V and the Nucleofector ${ }^{\mathrm{TM}}$ II device (Lonza). Four days after transfection, cells were subjected to selection for antibiotic resistance by supplementing their culture medium with $500 \mu \mathrm{g} / \mathrm{ml}$ of geneticin (G418, Invitrogen). Resistant cells were propagated to establish the PAC2-zGR $\beta$ cell line. For gene expression analysis, PAC2 wild type and PAC2-zGR $\beta$ cells were seeded in 6 -well plates $\left(2 \times 10^{5}\right.$ cells/well $)$ the day before treatment with $10 \mu \mathrm{M}$ betamethasone 17 -valerate (Sigma) or vehicle ( $2 \%$ DMSO) for $3 \mathrm{~h}$. Samples were collected in TRIzol ${ }^{\mathbb{R}}$ reagent (Invitrogen) and total RNA was isolated following the manufacturer's instructions (Invitrogen).

\subsection{RNA isolation \& $C D N A$ synthesis}

Total RNA was extracted using the TRIzol ${ }^{\circledR}$ reagent (Invitrogen) according to the manufacturer's instructions. RNA was dissolved in water and denatured for $5 \mathrm{~min}$ at $60^{\circ} \mathrm{C}$. Samples were treated with DNase using the DNA-free ${ }^{\mathrm{TM}}$ kit (Ambion). For microarray analysis, RNA was further purified using the RNeasy MinEluteTM Cleanup kit from Qiagen and its integrity was checked with a lab-on-a-chip analysis using the 2100 Bioanalyzer (Agilent Technologies). For subsequent cDNA synthesis, at least 200 ng of total RNA was added as a template for reverse transcription using the iSCRIPTTM cDNA Synthesis Kit (Biorad). 


\subsection{Quantitative Polymerase Chain Reaction ( $q P C R$ ) analysis}

qPCR analysis was performed using the MyiQ Single-Color RealTime PCR Detection System (Biorad). A detailed description of the qPCR analysis is provided in the Supplemental.

Methods section. In all qPCR experiments, a non-reverse transcribed sample and a water-control were included. All cDNA samples were assayed in duplicate. Values shown are means \pm s. e.m of three experiments. Sequences of all primers used for qPCR analysis are presented in Suppl. Table1.

\subsection{Zebrafish strains, husbandry \& egg collection}

Wild type adult ABxTL zebrafish and the transgenic lines $\operatorname{Tg}(\text { hsp70l:Gal4) })^{1.5 k c a 4}$ ((Scheer et al., 2001) provided by Dr. H. Baier, University of California, San Francisco, USA) and $\operatorname{Tg}(U A S: G F P-z G R \beta)$ were used in this study. Livestock was maintained and handled according to the guidelines from http://zfin.org. Fertilization was performed by natural spawning at the beginning of the light period and eggs were raised at $28{ }^{\circ} \mathrm{C}$ in E3 egg water medium containing $60 \mu \mathrm{g} / \mathrm{ml}$ Instant Ocean sea salts supplemented with $0.0025 \%$ methylene blue (GURR). All experimental procedures were conducted in compliance with the directives of the animal welfare committee of Leiden University.

\subsection{The $\operatorname{Tg}(U A S: G F P-z G R \beta)$ transgenic line, heat shock and glucocorticoid treatment}

The generation of the $\operatorname{Tg}(U A S: G F P-z G R \beta)$ line is described in the Supplemental Methods section. The Tg(hsp70l:Gal4) ${ }^{1.5 k c a 4}$ and $\mathrm{Tg}(U A S: G F P-z G R \beta)$ lines were crossed and their offspring were heatshocked at $1 \mathrm{dpf}$ in Petri dishes filled with pre-warmed $\left(37^{\circ} \mathrm{C}\right) \mathrm{E} 3$ egg water medium in a $37{ }^{\circ} \mathrm{C}$ incubator for $2.5 \mathrm{~h}$. The next day, embryos were screened for GFP expression and wild types as well as their GFP expressing siblings were subjected again to the heat shock protocol. Three-day-old hatched wild types and their GFP expressing siblings were checked again for GFP signal and treated with either vehicle ( $<2 \%$ DMSO) or the specific GR agonist beclomethasone $(25 \mu \mathrm{M})$ for $6 \mathrm{~h}$. Samples were collected in TRIzol ${ }^{\circledR}$ reagent (Invitrogen) for subsequent RNA isolation.

\subsection{Microarray analysis}

A $4 \times 180 \mathrm{k}$ microarray chip platform (customized by Agilent Technologies, (Design ID:028233)) was used in this study. This array consists of all probes already present in an earlier 45.219 custom-made array (Stockhammer et al., 2010), and another 126.632 newly designed zebrafish probes had been added as described in Rauwerda et al., (2010). A total of 16 samples (4 experimental groups from 4 replicate experiments) were processed for transcriptome analysis. On each $4 \times 180 \mathrm{k}$ slide, 4 samples from the different experimental groups within the same replicate were hybridized against a common reference. The microarray was performed and analyzed as described previously (Chatzopoulou et al., 2015, 2016), and details can be found in the Supplemental Methods section. The raw data from the microarray experiment were submitted to the Gene Expression Omnibus database under accession number GSE84906. Data analysis was performed setting cutoff for the $p$-value of $<10^{-5}$ and for fold change of either $>2$ or $<-2$.

\subsection{Gene ontology analysis}

As a starting point for the gene ontology analysis of the microarray results, clusters of genes were analyzed using the online functional classification tool DAVID (http://david.abcc.ncifcrf.gov/ summary.jsp). In addition, for genes not classified by DAVID, information was gathered on their function using the websites GeneCards (http://www.genecards.org/), National Center for Biotechnology Information (http://www.ncbi.nlm.nih.gov/gene), Genetics Home Reference (http://www.ncbi.nlm.nih.gov/gene), and Wikipedia (http://en.wikipedia.org/wiki/). Using this information, all genes were classified in one of the categories assigned by DAVID, or in a new category.

\subsection{Statistical analysis}

Statistical analyses (t-tests and two-way ANOVAs with Bonferroni post-hoc tests) were performed using the GraphPad Prism version 4.00 (GraphPad Software, La Jolla, USA).

\section{Results}

\subsection{Dominant-negative activity of $z G R \beta$ in COS-1 cells}

Previously, we have demonstrated that zGR $\beta$ has a dominantnegative effect on zGR $\alpha$-mediated transactivation of an MMTV:luciferase construct in COS-1 cells (Schaaf et al., 2008). In the present study, we aimed at studying this effect in more detail. First, COS1 cells were transiently transfected with an MMTV:luciferase reporter construct and a range of zGR $\alpha$ expression vector amounts with and without cotransfection of a zGR $\beta$ expression vector. Cells were incubated with $100 \mathrm{nM}$ dexamethasone (dex) for $24 \mathrm{~h}$ and assayed for luciferase activity. The results show that the luciferase activity was increased upon increasing concentrations of zGR $\alpha$ (Fig. 1A). In the presence of $z G R \beta$, the luciferase activity was strongly reduced, even when equal amounts of the $\mathrm{zGR} \alpha$ and $\mathrm{zGR} \beta$ expression vector were transfected. These data demonstrate that zGR $\beta$ exhibits a dominant-negative effect on the transcriptional properties of zGR $\alpha$ on a GRE-containing promoter in these reporter assays.

In order to study the effect of zGR $\beta$ on the DNA-binding independent activity of $\mathrm{zGR} \alpha$, cells were transiently transfected with a $\kappa \mathrm{B}$ :luciferase construct, an expression vector for the human p65 subunit of the NF- $\kappa B$ transcription factor complex and a range of zGR $\alpha$ expression vector amounts, with and without cotransfection of a zGR $\beta$ expression vector. Cells were incubated with $100 \mathrm{nM}$ dex for $24 \mathrm{~h}$ and assayed for luciferase activity. The results reveal that with increasing concentrations of $\mathrm{zGR} \alpha, \mathrm{NF}-\kappa \mathrm{B}-$ mediated luciferase activity was dramatically reduced (Fig. 1B). In these experiments, the presence of zGR $\beta$ did not affect the observed luciferase activity levels, indicating that $z G R \beta$ does not act as a dominant-negative inhibitor on the DNA-binding independent activity of zGR $\alpha$.

\subsection{Dominant-negative activity of $z G R \beta$ in PAC2 cells}

In order to study the effect of zGR $\beta$ on endogenous promoters in vitro, we generated a PAC2 cell line that stably overexpressed the zebrafish GR $\beta$-isoform (PAC2-zGR $\beta$ ). In PAC2-zGR $\beta$ cells, the zGR $\beta$ mRNA expression level was 260 fold higher than in wild type PAC2 cells (PAC2-wt), whereas the expression of $\mathrm{zGR} \alpha$ was not different between these two cell lines (Fig. 2A and B). That renders zGR $\beta$ as the predominant GR splice variant in the PAC2-zGR $\beta$ line, with a 10fold higher absolute mRNA abundance than that of $\mathrm{zGR} \alpha$ (Suppl. Fig.2).

The expression profile of a well-known endogenous GR target gene, fkbp5 (Schaaf et al., 2009), was investigated upon incubation with $10 \mu \mathrm{M}$ betamethasone-17-valerate (BV) by means of qPCR. Upon BV treatment, a more than 10 -fold induction of $f k b p 5$ was observed in both PAC2-wt and PAC2-zGR $\beta$ cells. Surprisingly, the induction of the fkbp5 gene upon BV administration was not 
A

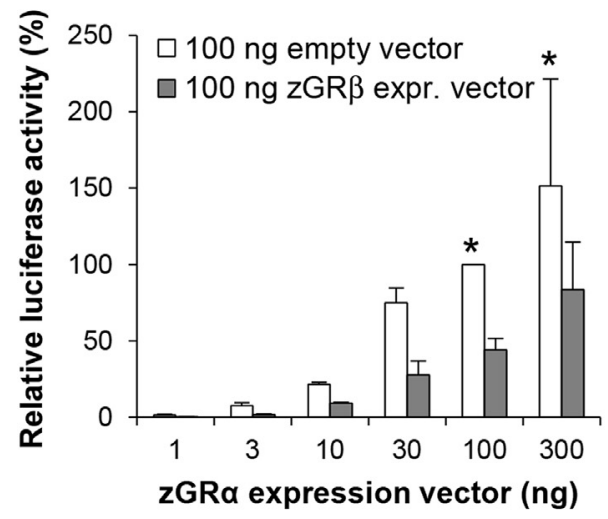

B

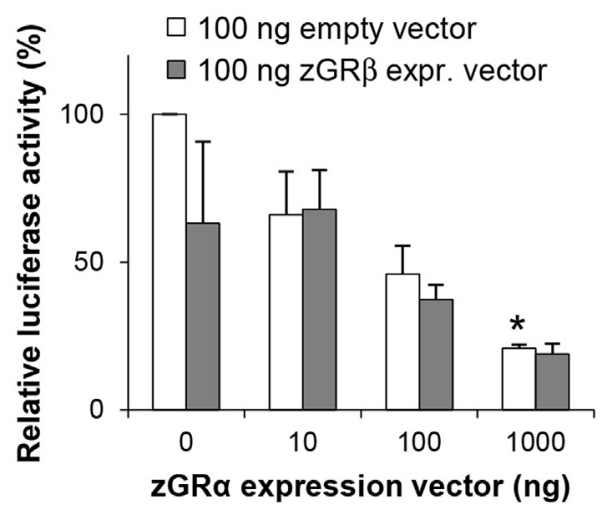

Fig. 1. A. Dominant-negative activity of zGR $\beta$ on transactivation analyzed by luciferase assays. COS- 1 cells were transiently transfected with an MMTV-luciferase reporter construct and a range of $\mathrm{zGR} \alpha$ expression vector amounts in absence (white bars) and presence (grey bars) of $100 \mathrm{ng}$ zGR $\beta$, and incubated with $100 \mathrm{nM}$ dex for $24 \mathrm{~h}$. The relative luciferase activity values (setting the $100 \mathrm{ng} z \mathrm{GR} \alpha$ transfected group value as $100 \%$ ) shown are the means \pm s. e.m. of three independent experiments. Statistical analysis by ANOVA revealed an effect of zGR $\beta$ expression $(\mathrm{p}=0.001)$. Asterisks $\left({ }^{*}\right)$ indicate a statistically significant difference $(\mathrm{p}<0.05)$ from the corresponding control group ( $1 \mathrm{ng} z \mathrm{GR} \alpha$ ). B. Lack of dominant-negative activity of $z \mathrm{GR} \beta$ on repression activity analyzed by luciferase assays. COS- 1 cells were transiently transfected with a $\kappa B-$ luciferase construct, an expression vector for the human p65 subunit of the NF- $\kappa B$ transcription factor complex and a range of $\mathrm{zGR} \alpha$ expression vector amounts in the absence (white bars) and presence (grey bars) of $100 \mathrm{ng}$ zGR $\beta$ plasmid, and incubated with $100 \mathrm{nM}$ dex for $24 \mathrm{~h}$. The relative luciferase activity values (setting the $0 \mathrm{ng} z \mathrm{GR} \alpha$ transfected group value as $100 \%$ ) shown are the means \pm s. e.m. of three independent experiments. Statistical analysis by ANOVA demonstrated no significant effect of zGR $\beta$ expression. Asterisks $\left({ }^{*}\right)$ indicate a statistically significant difference $(\mathrm{p}<0.05)$ from the corresponding control group ( $0 \mathrm{ng} \mathrm{zGR} \alpha)$.

statistically different between the PAC2-wt and PAC2-zGR $\beta$ line (Fig. 2C). Thus, zGR $\beta$ does not exhibit any dominant-negative activity on zGR $\alpha$-induced transactivation of the $f k b p 5$ gene in PAC2 cells. Several other known GR target genes (gilz, slc $5 \alpha 1$, agtxb, $h s d 11 b 2$, pepck, $n f k b i \alpha \alpha$ ) were tested for induction upon BV treatment in PAC2 cells as well, but none of these genes showed increased mRNA expression, leaving $f k b p 5$ as the only confirmed GR target gene in these cells.

\subsection{Generation of a $\mathrm{Tg}$ (hsp70l:Gal4/UAS:GFP-zGR $\beta$ ) transgenic line}

Subsequently a fish line was generated in which the zGR $\beta$ expression was induced upon a heat shock. We generated a $\mathrm{Tg}$ (UAS:GFP-zGRß) line, containing a construct encompassing a cDNA encoding a GFP-tagged zGR $\beta$ positioned downstream of a

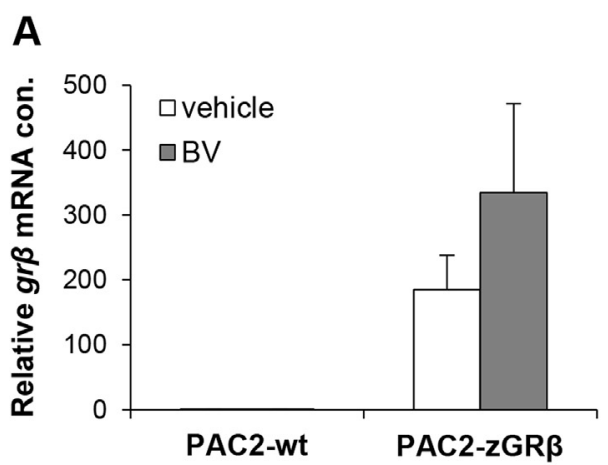

B
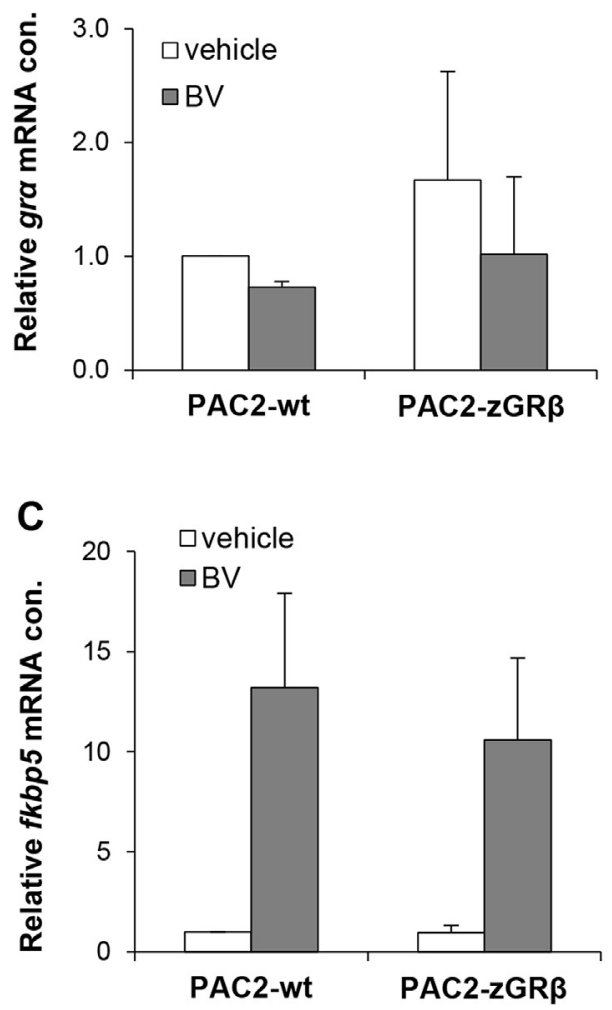

Fig. 2. A. Stable overexpression of the zebrafish GR $\beta$-isoform in PAC2 cells. Cells were stably transfected with a zGR $\beta$ expression vector for the generation of the PAC2-zGR $\beta$ line. The $z G R \beta$ expression level of this cell line was determined by qPCR. The data show that the PAC2-zGR $\beta$ cell line highly overexpresses ( $>250$ fold) the $z G R \quad \beta$-isoform compared to its parental wild type line. Stimulation of both lines with $10 \mu \mathrm{M}$ BV (betamethasone-17-valerate) for $3 \mathrm{~h}$ did not significantly affect zGR $\beta$ mRNA expression. B. Expression levels of zGR $\alpha$ mRNA in PAC2-wt and PAC2-zGR $\beta$ cells treated with either $10 \mu \mathrm{M}$ BV or vehicle for $3 \mathrm{~h}$. Statistical analysis by ANOVA demonstrated that there is no significant effect on the expression of the zGR $\alpha$-isoform due to either BV treatment or overexpression of the zGR $\beta$-isoform. C. Expression levels of $f k b p 5$ mRNA in PAC2-wt and PAC2-zGR $\beta$ cells, determined by qPCR. Cells from both lines were compared for their ability to upregulate the expression of $f k b p 5$ upon treatment with either $10 \mu \mathrm{M}$ BV or vehicle for $3 \mathrm{~h}$. Statistical analysis revealed that $f k b p 5$ induction due to BV treatment does not differ between the two lines examined. In all figures mRNA expression measurements were normalized to those of bactin 1 and the relative mRNA concentration values are the means \pm s. e.m. of three independent experiments.

14xUAS promoter that is activated by the Gal4 transcription factor. This line was crossed with the $\operatorname{Tg}(\text { hsp } 70 l: G a l 4)^{1.5 k c a 4}$ line (in which Gal4 expression is controlled by a heat shock-inducible promoter), yielding the $\mathrm{Tg}$ (hsp70l:Gal4/UAS:GFP-zGR/) line. Embryos from this line at 1 and 2 day post fertilization (dpf) were heat shocked and the GFP signal was readily detectable within a few hours. Expression was clearly present in cells in the muscles and eyes, and in cells 
lining the yolk sac of 3dpf larvae (Fig. 3B). Further magnification suggested that GFP-zGR $\beta$ is localized in the nuclei of the cells (Fig. 3C), which was confirmed by co-staining with Sytox Orange (data not shown).

In order to confirm that the fusion protein was properly expressed, qPCR analysis showed that in the fluorescent larvae GR $\beta$ mRNA levels were increased 22-fold compared to non-fluorescent (wild type) larvae (Suppl. Fig.3). Using a previously characterized expression vector for YFP-tagged zGR $\beta$ (Schaaf et al., 2008), we showed in COS- 1 cells that this type of tag does not affect zGR $\beta$ 's dominant-negative activity (Suppl. Fig.4).

\subsection{Microarray analysis of $z G R \beta$ activity using the $\operatorname{Tg}$ (hsp70l:Gal4/ UAS:GFP-zGR $\beta$ ) line}

Next it was explored at the whole transcriptome level whether zGR $\beta$ plays a functional role in transcriptional regulation, using a custom-designed microarray platform (Rauwerda et al., 2010). The $\mathrm{Tg}$ (hsp70l:Gal4) $)^{1.5 k c a 4}$ line was crossed with the $\operatorname{Tg}($ UAS:GFP-zGRß) line. The resulting embryos were identified, upon heat shock, based on the observed fluorescence as either wild type (lacking fluorescence, referred to as WT) or GFP-zGR $\beta$-overexpressing (showing green fluorescence, referred to as GR $\beta$ ). Both populations were treated with either $25 \mu \mathrm{M}$ beclomethasone (beclo) or vehicle (veh) for $6 \mathrm{~h}$ at $3 \mathrm{dpf}$. Thus, 4 groups were generated: WT/veh, WT/beclo, GR $\beta /$ veh, GR $\beta$ /beclo (Fig. 4A). Total RNA samples from 4 biological replicates (16 samples in total) were processed for the microarray study using a common reference design. Data were analyzed using Rosetta Resolver 7.2 software, setting signatures for significantly regulated probes at a $\mathrm{p}$-value cutoff of $\mathrm{p}<10^{-5}$ and fold changes either $>2$ or $<-2$.

As a first step, we studied genes regulated upon beclo treatment in the wild type fish (comparison WT/veh vs. WT/beclo). We identified 2508 probes corresponding to genes significantly regulated by beclo treatment (1805 up, 703 down). Of these probes, 1592 could be attributed to an annotated gene, yielding a total of 907 genes identified as beclo-regulated. For 13 randomly chosen, validation by qPCR was performed, and a significant effect of beclo treatment was confirmed for all genes tested (Suppl. Fig.5). Gene ontology analysis showed that 137 genes in this cluster were involved in metabolic processes, of which 38 in the metabolism of carbohydrates, 37 in protein metabolism, and 18 in lipid metabolism. Other gene ontology groups overrepresented in this cluster were those containing genes involved in membrane transport (67 genes), genes encoding transcription factors (58), and genes involved in cell cycle and apoptosis (49). An overview of the gene ontology analysis of this cluster is presented in Fig. 4B, and detailed information is presented in Suppl. Table2.

In order to examine a dominant-negative effect of $z G R \beta$, we studied the effect of $z G R \beta$ overexpression on gene regulation upon beclo administration. For this purpose, the level of regulation by beclo after GFP-zGR $\beta$ overexpression (comparison GR $\beta /$ veh vs. GR $\beta$ / beclo) was plotted against the regulation by beclo without GFPzGR $\beta$ overexpression (comparison WT/veh vs. WT/beclo), for all probes significantly regulated in at least one of these comparisons (Fig. 5A). The resulting scatter plot shows that generally gene regulation by beclo is not different between these two conditions. Thus, this analysis shows no evidence for a dominant-negative activity of zGR $\beta$ on $z G R \alpha$-mediated gene transcription induced by beclo. Since GFP-GR $\beta$ overexpression levels were particularly high in muscle cells (Fig. 3), a similar plot was made using only data from probes corresponding to genes involved in muscle function and/or muscle development (Suppl. Fig.6), showing a similar lack of evidence for a dominant-negative effect.

To study a possible dominant-negative activity of zGR $\beta$ more specifically, regulation for all 2508 probes regulated by beclo was compared between the WT/beclo and the zGR $\beta /$ beclo group. Of the 1805 probes corresponding to beclo-upregulated genes, 30 genes showed a downregulation upon overexpression of zGR $\beta$ (in the presence of beclo). These data indicate a dominant-negative effect of zGR $\beta$ (Fig. 5B). In addition, for 35 of the 703 probes corresponding to genes downregulated by beclo treatment, an upregulation was observed upon overexpression of zGR $\beta$ (in the presence of beclo), also indicating a dominant-negative effect of zGR $\beta$ (Fig. 5C). Thus, in our microarray experiment, a significant inhibitory activity of $\mathrm{zGR} \beta$ on $\mathrm{zGR} \alpha$-induced transcriptional regulation was detected for 65 probes, which accounts for $2.6 \%$ of all becloregulated probes. Within the cluster of 65 probes that indicated a dominant-negative activity of zGR $\beta, 31$ probes could be attributed to 29 genes. Eight randomly chosen genes from this cluster were used for validation of the microarray results by qPCR. In this validation, we could not verify any significant $z G R \beta$ dominant-negative effect on any of the genes tested (Suppl. Fig.7).

Finally, we investigated whether zGR $\beta$ has intrinsic transcriptional activity, able to regulate the expression of target genes independently of zGR $\alpha$ activity. For that reason, we compared the WT/veh and GR $\beta /$ veh groups and we identified 258 probes corresponding to up-regulated transcripts due to the zGR $\beta$ overexpression and 223 probes corresponding to down-regulated ones. These 481 regulated probes be attributed to 193 annotated genes.
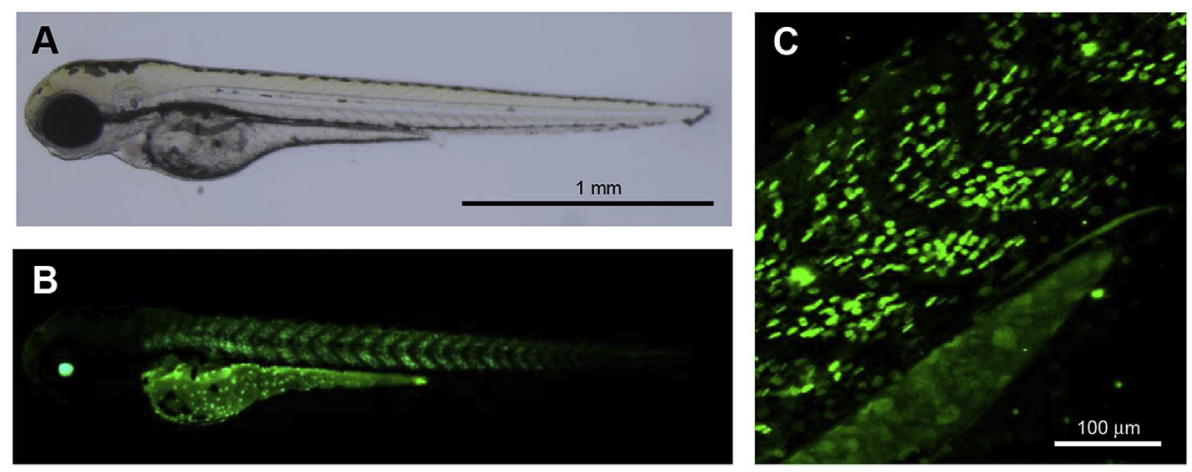

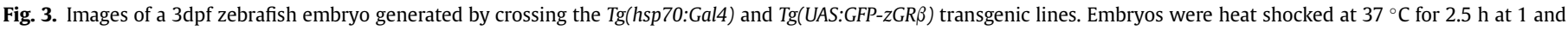

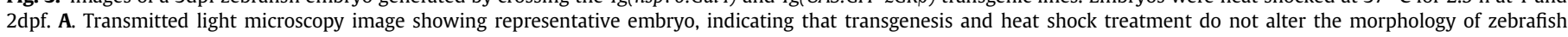

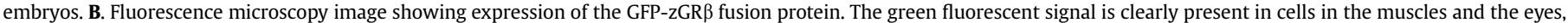

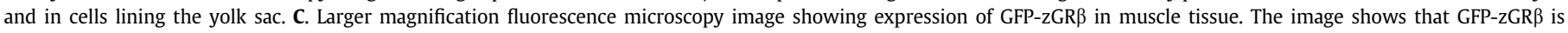
localized in the nuclear cell compartment. 


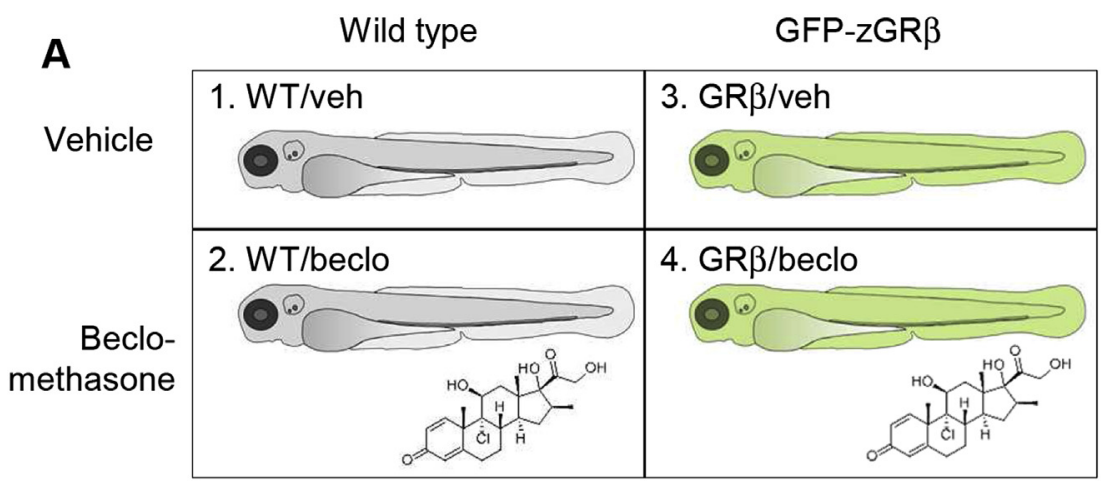

B

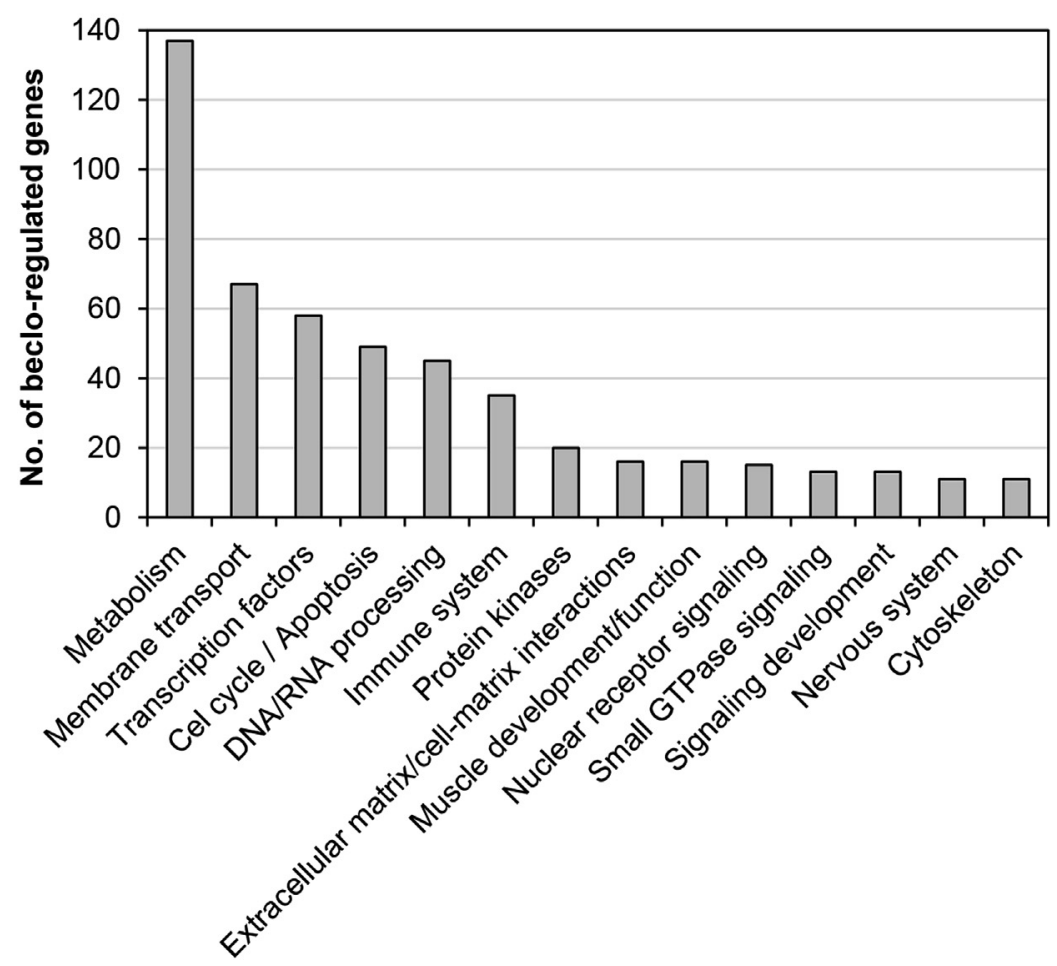

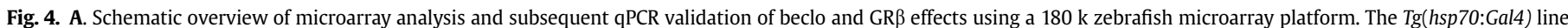

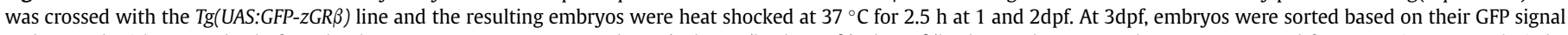

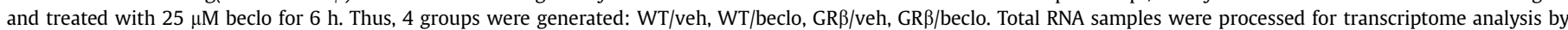

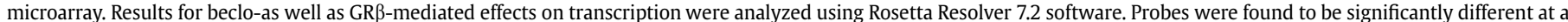

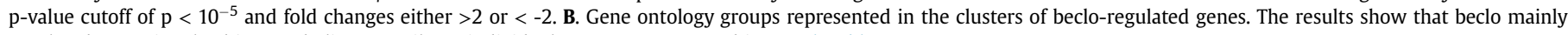
regulated genes involved in metabolism. Details on individual genes are presented in Suppl. Table2.

Gene ontology analysis showed that genes encoding transcription factors (18) and genes involved in metabolism (17) were overrepresented, as well as genes involved in DNA/RNA processing, (11), membrane transport (10) and the nervous system (10). An overview of the gene ontology analysis of this cluster is presented in Fig. 6A, and detailed information is presented in Suppl. Table3. These overrepresented gene ontology groups are clearly different from the groups overrepresented in the beclo-regulated cluster (Fig. 4), and further comparison between these clusters shows that from the 481 probes regulated upon GFP-zGR $\beta$ overexpression, only 76 were also in the cluster of genes regulated by beclo (Fig. 6B). These data indicate that GFP-zGR $\beta$ regulates a different cluster of genes than beclo, which is further demonstrated in a scatter plot in which the regulation upon GFP-zGR $\beta$ overexpression is plotted against the regulation upon beclo administration for all probes regulated by at least one of these treatments (Suppl. Fig.8). From the cluster of 193 genes, 10 randomly selected genes were used for validation. Again, qPCR analysis failed to verify any significant zGR $\beta$ effect on any gene tested (Suppl. Fig.9).

Validation by qPCR failed for the regulation of genes due to GFPzGR $\beta$ overexpression (dominant-negative or intrinsic transcriptional activity), whereas gene regulation due to beclo treatment was confirmed in all cases studied. This prompted us to further investigate differences between the clusters of beclo- and zGR $\beta$ regulated genes. We found that a more stringent analysis of the microarray data dramatically decreases the size of the clusters of zGR $\beta$-regulated genes, whereas it has a much smaller impact on the cluster of beclo-regulated ones. For example, using a significance threshold of $\mathrm{p}=10^{-10}$, instead of $\mathrm{p}=10^{-5}$ as done in this study, zGR $\beta$ would show a dominant-negative effect on only $17 \%$ of the 65 probes found at $\mathrm{p}=10^{-5}$ and an intrinsic transcriptional activity on only $22 \%$ of the 105 probes found at $\mathrm{p}=10^{-5}$. In contrast, beclo 


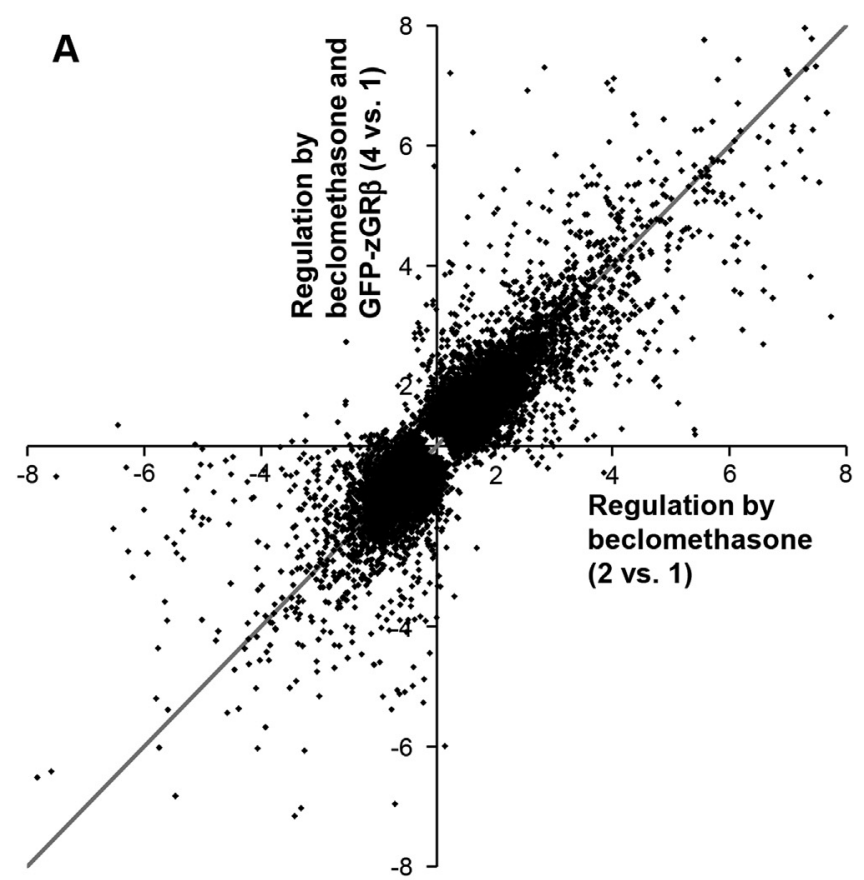

B Upregulated by beclomethasone $(2>1)$

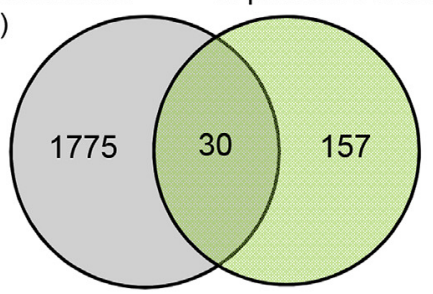

Downregulated by GFP-zGR $\beta$ in presence of beclomethasone $(4<2)$

Downregulated by
beclomethasone Upregulated by GFP-zGR $\beta$ $(2<1)$

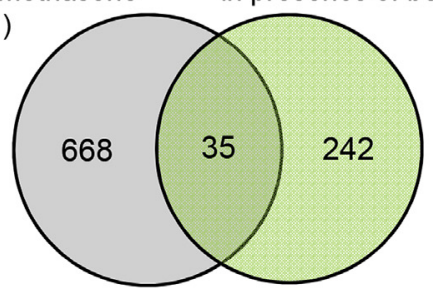
$(4>2)$

Fig. 5. Analysis of a possible dominant-negative activity of GFP-GR $\beta$. A. Scatter plot showing the level of gene regulation upon beclo treatment (WT/veh vs WT/beclo) plotted against regulation of genes by beclo treatment after GFP-zGR $\beta$ overexpression (GR $\beta /$ veh vs GR $\beta /$ beclo). Data points indicate levels for individual probes. Data are shown for probes that were significantly regulated at least 2 -fold by one or both of these treatments. The plotted line indicates points where beclo regulation without GR $\beta$ overexpression equals beclo regulation upon GR $\beta$ overexpression. The scatter plot shows that generally beclo regulates gene expression after similarly to regulation with and without GR $\beta$ overexpression, so this analysis shows no evidence for a general dominant-negative activity of zGR $\beta$ on zGR $\alpha$-mediated gene regulation. B. Venn diagram showing the cluster of genes of which the beclo-induced upregulation is attenuated by GR $\beta$. This cluster is represented by the overlap between the cluster of genes upregulated by beclo (WT/beclo > WT/veh, grey circle) and the cluster of genes downregulated by GFP-zGR $\beta$ overexpression in the presence of beclo (GR $\beta$ / beclo $<\mathrm{WT}$ /beclo, green circle). C. Venn diagram showing the cluster of genes of which the beclo-induced downregulation is attenuated by GR $\beta$, represented by the overlap between the cluster of genes downregulated by beclo (WT/beclo $<\mathrm{WT} /$ veh, grey circle) and the cluster of genes upregulated by GFP-zGR $\beta$ overexpression in the presence of beclo (GR $\beta /$ beclo $>W T /$ beclo, green circle). (For interpretation of the references to colour in this figure legend, the reader is referred to the web version of this article.) treatment would significantly still affect $72 \%$ of the 2508 found at $\mathrm{p}=10^{-5}$. Alternatively, limiting the analysis to genes that show regulation for at least two probes would have left very few zGR $\beta$ regulated genes ( 2 for $z G R \beta$ dominant-negative activity and 4 for zGR $\beta$ intrinsic transcriptional activity), whereas still a significant number of beclo-regulated probes (302) would have been found. This shows that the relative number of false-positives among the zGR $\beta$-regulated genes is considerably larger than among the becloregulated genes, which was reflected in the data of our qPCR validation.

\section{Discussion}

In the present study we have used the zebrafish as a model organism to investigate the regulatory role of the zebrafish GR $\beta$ isoform in gene transcription. We initially looked at its dominantnegative effect on the transcriptional properties of the GR $\alpha$-isoform. By means of luciferase reporter assays using transient transfections in COS- 1 cells we demonstrated that zGR $\beta$ strongly inhibits zGR $\alpha$ 's transcriptional activity on a GRE-containing promoter, even when we transfected equal amounts of zGR $\alpha$ and zGR $\beta$ expression vectors. This dominant-negative activity had already been observed in our laboratory using a 1:10 zGR $\alpha / z G R \beta$ ratio.

(Schaaf et al., 2008). It recapitulates data obtained in similar reporter assays in which the human GR $\beta$ (Bamberger et al., 1995; Charmandari, 2004; Oakley et al., 1999; Yudt et al., 2003) and mouse GR $\beta$ (Hinds et al., 2010) showed a dominant-negative effect at $1: 10$ and $1: 2 \alpha / \beta$ transfection ratio, respectively. In contrast, we did not observe an effect of zGR $\beta$ on the ability of $\mathrm{zGR} \alpha$ to repress $\mathrm{NF}-\kappa \mathrm{B}$ activity in an in vitro reporter assay. The specificity of the dominant-negative activity of GR $\beta$ for the DNA-binding dependent transcriptional activity of GR $\alpha$ has also been shown for the human GR $\beta$-isoform in numerous studies in which similar sets of experiments were performed (Bamberger et al., 1997; Gougat et al., 2002; Kelly et al., 2008; Kim et al., 2009), even at a 1:20 $\alpha / \beta$ transfection ratio in COS-7 cells (Brogan et al., 1999). In contrast, one study has demonstrated a specific dominant-negative effect of hGR $\beta$ on the $h G R \alpha$-induced repression of gene regulation by NF- $\kappa B$ and CREB (Taniguchi et al., 2010) and a dominant-negative effect on the dexinduced repression of TNF $\alpha$ and IL6 expression was demonstrated in human monocytes ( $\mathrm{Li}, 2006$ ).

We next addressed the question whether zGR $\beta$ also exhibits dominant-negative properties on the $\mathrm{zGR} \alpha$-induced transactivation of endogenous genes. From studies in human cell cultures there is a solid body of evidence that hGR $\beta$ inhibits hGR $\alpha$-induced activation of a number of endogenous genes (Goleva et al., 2006; Kino et al., 2009a,b; Li, 2006; Zhang, 2005). In the present study, we generated a PAC2 cell line that stably overexpressed zGR $\beta$. Surprisingly, we did not observe any effect of zGR $\beta$ overexpression on the zGR $\alpha$ induced activation of $f k b p 5$ gene (a well-known GR $\alpha$ target gene ( $U$ et al., 2004)). Thus, it appears that zGR $\beta$ does not exhibit a general dominant-negative activity on $\mathrm{zGR} \alpha$-induced gene activation. Interestingly, recent studies in mice reported a lack of GR $\beta$ overexpression effect on GR $\alpha$-induced $f k b p 5$ transcription, whereas a dominant-negative activity on other, mostly metabolism-related genes, was observed (Hinds et al., 2010). Unfortunately, due to a limited responsiveness of our PAC2 line to GC treatment, we were not able to assess the zGR $\beta$ inhibitory effect on other GR $\alpha$ target genes.

In order to get a genome-wide view of zGR $\beta$ 's transcriptional properties, we performed a transcriptome analysis upon zGR $\beta$ overexpression in vivo. We generated the $\operatorname{Tg}$ (hsp70:Gal4/UAS:GFP$z G R \beta)$ transgenic line. Using this in vivo transgenic model combined with a microarray approach, we initially found an effect of zGR $\beta$ overexpression on 481 probes (independent of zGR $\alpha$ activity), and 
A
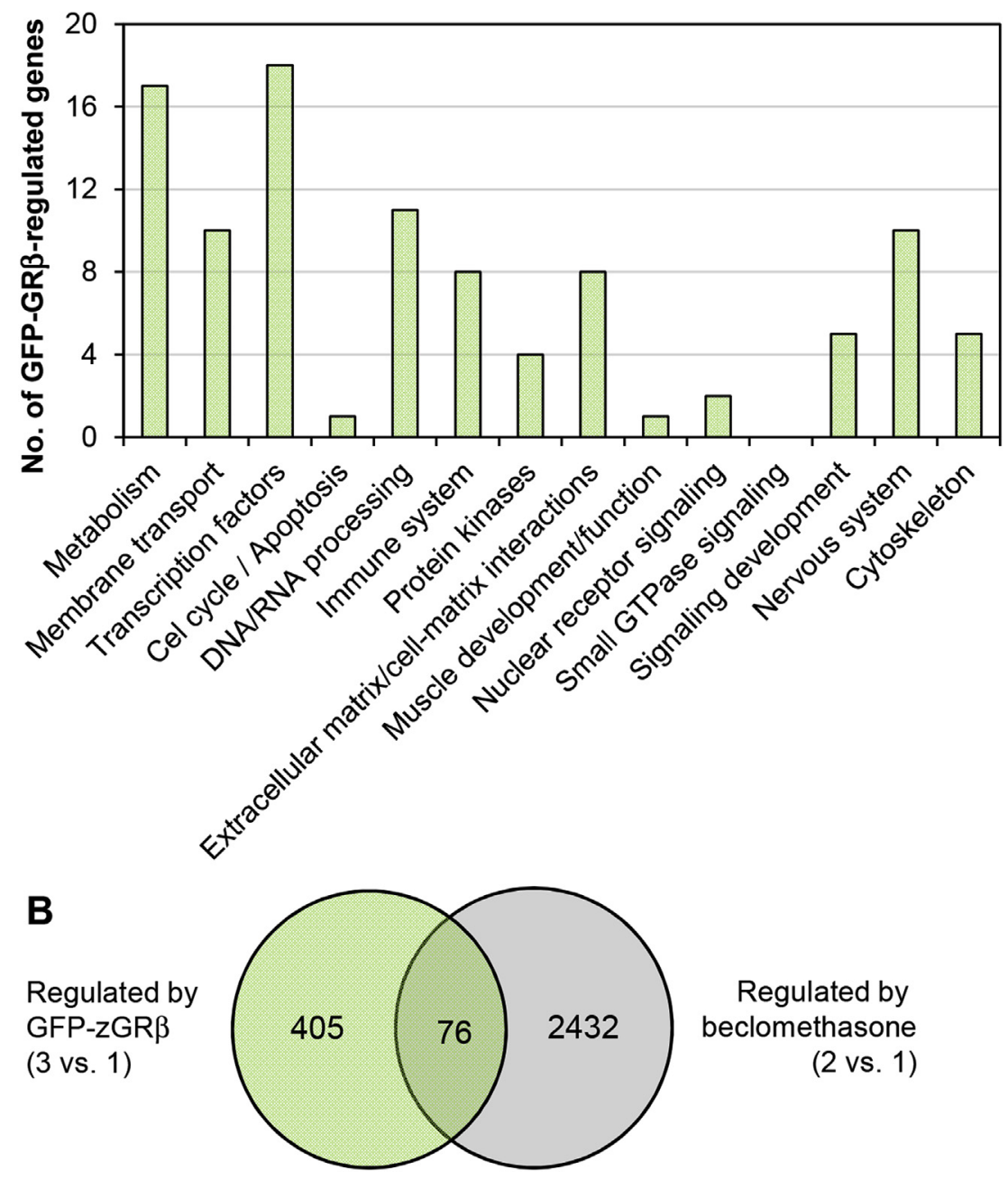

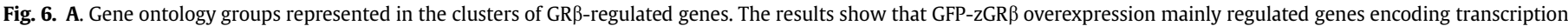

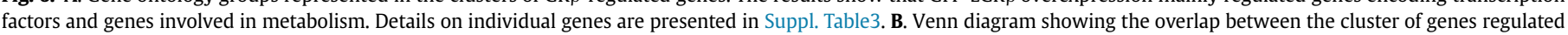

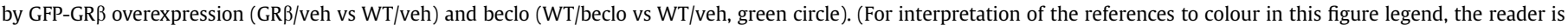
referred to the web version of this article.)

65 probes displayed a dominant-negative effect of zGR $\beta$. However, after careful analysis of the microarray data we concluded that at least the vast majority of these data represent false positive results. The distributions of p-values and number of probes per gene showing regulation within the subsets of zGR $\beta$-regulated genes was remarkably different from those found for the cluster of probes showing regulation by beclo treatment, raising questions about the confidence level of the results on zGR $\beta$ regulation. Indeed, using qPCR analysis of a set of genes showing regulation by zGR $\beta$ in the microarray we could not verify the effect of $z G R \beta$ on any of the selected genes. Using qPCR on genes showing regulation by beclo we could verify the results from the microarray on all selected genes, supporting the validity of our study.

These results led us to suggest that the effects of zGR $\beta$ on transcription in our transgenic zebrafish model are absent. Combined with the negative results obtained in PAC2 cells, our findings generally lack evidence for a transcriptional role for zGR $\beta$. These data are in line with our previous in vivo work on zGR $\beta$, in which we overexpressed this receptor isoform by injection of mRNA and a splice-blocking morpholino (Chatzopoulou et al., 2015). The results of this study showed no evidence for a dominant-negative activity, like the results of the present study. In addition, both the GR $\beta$ mRNA and the morpholino injection affected a cluster of genes, independent of zGR $\alpha$ activity ( 149 and 485 genes respectively). The overlap between these two clusters was small (13 genes), and overlap with the cluster of 193 genes regulated by GFP-GR $\beta$ in the present study was even smaller ( 3 and 5 genes respectively). Taken together, the inconsistency between the different studies suggests that the observed effects on gene expression gene were either nonspecific or off-target effects of the treatment or false-positive results. Furthermore, the studies on the zGR $\beta$-isoform presented here demonstrate that dominant-negative activity observed in reporter assays does not necessarily imply a similar effect on endogenous genes in vivo. This discrepancy probably originates from endogenous gene sequences being embedded in chromatin, which may make them less accessible to DNA-binding factors like GR $\beta$ than transiently transfected DNA constructs.

Recent transcriptome analyses have revealed that the vast majority of genes in vertebrate genomes are subject to alternative splicing, and that alternatively spliced mRNA isoforms are highly species-specific (Barbosa-Morais et al., 2012). Apparently, the alternative usage of exons changes rapidly during evolution. 
Indeed, we previously showed that the splicing pattern leading to the expression of GR $\beta$ in zebrafish is restricted to a relatively small group of fish (Schaaf et al., 2008), and that this is commonly observed for C-terminal splice variants of nuclear receptors (van der Vaart and Schaaf, 2009). Analysis of a variety of fish genomes (Suppl. Fig.10) demonstrated that important changes occurred in the organization of the GR gene after the Ostariophysii superorder (to which the zebrafish belongs) branched off the lineage that led to the Acantopterygii (110-160 million years ago). The sequence of the splice donor site at the 3 'end of exon 8 changed significantly and the length of intron 8 increased dramatically. These alterations did not immediately lead to a weak splice donor site and intron retention, but were most likely first steps towards enabling further evolution towards GR $\beta$ expression in zebrafish and possibly in other species.

The lack of an effect of the GR $\beta$-isoform in zebrafish presented in this study follows the trend of controversy over the physiological function of the GR $\beta$-isoform in humans. After more than 20 years of research, a consistent view on a possible dominant-negative activity in vivo is still lacking. The observations on the intrinsic transcription factor activity of hGR $\beta$ (Kino et al., 2009a,b; LewisTuffin et al., 2007) have recently added more inconsistent data, since a large set of genes appeared to be oppositely regulated by hGR $\beta$ in different studies (Kino et al., 2009a,b). Although our work on the functional role of GR $\beta$ in zebrafish does not support a transcriptional role for this GR isoform, we would like to be careful with extrapolating these results to the human situation, since the role of the human GR $\beta$-isoform may be different.

\section{Conclusions}

Taken together, our data indicate that zGR $\beta$ does not have a functional role in transcriptional regulation, although effects on a small subset of genes or effects highly specific for a certain tissue or condition can not be ruled out. Splicing of a GR pre-mRNA into a messenger encoding GR $\beta$ could be a physiological way to downregulate the levels of GR $\alpha$. In such a case, the GR $\beta$-isoform does not have an active inhibitory role but the generation of mRNA encoding this splice variant would result in a decreased expression of the canonical GR $\alpha$-isoform, thereby lowering the activity of the GC signaling pathway.

\section{Acknowledgements}

The authors would like to thank Dr. H. Baier (Max Planck Institute of Neurobiology, Germany) for kindly providing the transgenic line $\mathrm{Tg}(\mathrm{hsp} 70 \mathrm{l}: \mathrm{Gal} 4)^{1.5 \mathrm{kca} 4}$ and the 14xUAS E1b Tol2 transposonbased vector, as well as Dr. K. Kawakami for kindly providing the pME-MCS vector and pCS2FA-transposase plasmid. Additionally, the authors would like to gratefully acknowledge Huma Safdar, Enice Bagci and Özge Zelal Aydin for their technical assistance during the experiments, as well as Dr. Oliver W. Stockhammer for his assistance with the analysis of the microarray data.

\section{Appendix A. Supplementary data}

Supplementary data related to this article can be found at http:// dx.doi.org/10.1016/j.mce.2017.02.036.

\section{Funding}

The present work was financially supported by the SmartMix program of The Netherlands Ministry of Economic Affairs and the Ministry of Education, Culture and Science.

\section{Declaration of interest}

There is no conflict of interest that could be perceived as prejudicing the impartiality of the research reported.

\section{References}

U, M., Shen, L., Oshida, T., Miyauchi, J., Yamada, M., Miyashita, T., 2004. Identification of novel direct transcriptional targets of glucocorticoid receptor. Leukemia 18, $1850-1856$.

Bamberger, C.M., Bamberger, A.M., de Castro, M., Chrousos, G.P., 1995. Glucocorticoid receptor beta, a potential endogenous inhibitor of glucocorticoid action in humans. J. Clin. Invest. 95, 2435-2441.

Bamberger, C.M., Else, T., Bamberger, A.M., Beil, F.U., Schulte, H.M., 1997. Regulation of the human interleukin-2 gene by the alpha and beta isoforms of the glucocorticoid receptor. Mol. Cell Endocrinol. 136, 23-28.

Barbosa-Morais, N.L., Irimia, M., Pan, Q., Xiong, H.Y., Gueroussov, S., Lee, L.J., Slobodeniuc, V., Kutter, C., Watt, S., Colak, R., Kim, T., Misquitta-Ali, C.M., Wilson, M.D., Kim, P.M., Odom, D.T., Frey, B.J., Blencowe, B.J., 2012. The evolutionary landscape of alternative splicing in vertebrate species. Science 338, 1587-1593.

Beato, M., Klug, J., 2000. Steroid hormone receptors: an update. Hum. Reprod. Update 6, 225-236.

Brogan, I.J., Murray, I.A., Cerillo, G., Needham, M., White, A., Davis, J.R., 1999. Interaction of glucocorticoid receptor isoforms with transcription factors AP-1 and NF-kappaB: lack of effect of glucocorticoid receptor beta. Mol. Cell Endocrinol. 157, 95-104.

Buckingham, J.C., 2006. Glucocorticoids: exemplars of multi-tasking. Br. J. Pharmacol. 147 (Suppl. 1), S258-S268.

Carlstedt-Duke, J., 1999. Glucocorticoid receptor beta: view II. Trends Endocrinol. Metab. 10, 339-342.

Charmandari, E., 2004. The human glucocorticoid receptor (hGR) isoform suppresses the transcriptional activity of hGR by interfering with formation of active coactivator complexes. Mol. Endocrinol. 19, 52-64.

Chatzopoulou, A., Roy, U., Meijer, A.H., Alia, A., Spaink, H.P., Schaaf, M.J., 2015. Transcriptional and metabolic effects of glucocorticoid receptor alpha and beta signaling in zebrafish. Endocrinology 156, 1757-1769.

Chatzopoulou, A., Heijmans, J.P., Burgerhout, E., Oskam, N., Spaink, H.P., Meijer, A.H., Schaaf, M.J., 2016. Glucocorticoid-induced attenuation of the inflammatory response in zebrafish. Endocrinology 157, 2772-2784.

Christodoulopoulos, P., Leung, D.Y.M., Elliott, M.W., Hogg, J.C., Muro, S., Toda, M. Laberge, S., Hamid, Q.A., 2000. Increased number of glucocorticoid receptor$\beta$-expressing cells in the airways in fatal asthma w. J. Allergy Clin. Immunol. 106, 479-484.

Chrousos, G.P., Kino, T., 2005. Intracellular glucocorticoid signaling: a formerly simple system turns stochastic, 2005 Sci. STKE pe48.

De Bosscher, K., Haegeman, G., 2009. Minireview: latest perspectives on antiinflammatory actions of glucocorticoids. Mol. Endocrinol. 23, 281-291.

de Castro, M., Elliot, S., Kino, T., Bamberger, C., Karl, M., Webster, E., Chrousos, G.P., 1996. The non-ligand binding beta-isoform of the human glucocorticoid receptor (hGR beta): tissue levels, mechanism of action, and potential physiologic role. Mol. Med. 2, 597-607.

de Kloet, E.R., Joels, M., Holsboer, F., 2005. Stress and the brain: from adaptation to disease. Nat. Rev. Neurosci. 6, 463-475.

Derijk, R.H., Schaaf, M.J., Turner, G., Datson, N.A., Vreugdenhil, E., Cidlowski, J., de Kloet, E.R., Emery, P., Sternberg, E.M., Detera-Wadleigh, S.D., 2001. A human glucocorticoid receptor gene variant that increases the stability of the glucocorticoid receptor beta-isoform mRNA is associated with rheumatoid arthritis. J. Rheumatol. 28, 2383-2388.

Encio, I.J., Detera-Wadleigh, S.D., 1991. The genomic structure of the human glucocorticoid receptor. J. Biol. Chem. 266, 7182-7188.

Fujishima, S.-i., Takeda, H., Kawata, S., Yamakawa, M., 2009. The relationship between the expression of the glucocorticoid receptor in biopsied colonic mucosa and the glucocorticoid responsiveness of ulcerative colitis patients. Clin. Immunol. 133, 208-217.

Goecke, A., Guerrero, J., 2006. Glucocorticoid receptor $\beta$ in acute and chronic inflammatory conditions: clinical implications. Immunobiology 211, 85-96.

Goleva, E., Li, L.B., Eves, P.T., Strand, M.J., Martin, R.J., Leung, D.Y., 2006. Increased glucocorticoid receptor beta alters steroid response in glucocorticoidinsensitive asthma. Am. J. Respir. Crit. Care Med. 173, 607-616.

Gougat, C., Jaffuel, D., Gagliardo, R., Henriquet, C., Bousquet, J., Demoly, P., Mathieu, M., 2002. Overexpression of the human glucocorticoid receptor $\alpha$ and $\beta$ isoforms inhibits AP-1 and NF- $\mathrm{KB}$ activities hormone independently. J. Mol. Med. 80, 309-318.

Hamid, Q.A., Wenzel, S.E., Hauk, P.J., Tsicopoulos, A., Wallaert, B., Lafitte, J.J., Chrousos, G.P., Szefler, S.J., Leung, D.Y., 1999. Increased glucocorticoid receptor beta in airway cells of glucocorticoid-insensitive asthma. Am. J. Respir. Crit. Care Med. 159, 1600-1604.

Hamilos, D.L., Leung, D.Y.M., Muro, S., Kahn, A.M., Hamilos, S.S., Thawley, S.E., Hamid, Q.A., 2001. GR $\beta$ expression in nasal polyp inflammatory cells and its relationship to the anti-inflammatory effects of intranasal fluticasone r. $^{2}$. J. Allergy Clin. Immunol. 108, 59-68.

Hauk, P.J., Goleva, E., Strickland, I., Vottero, A., Chrousos, G.P., Kisich, K.O., 
Leung, D.Y., 2002. Increased glucocorticoid receptor Beta expression converts mouse hybridoma cells to a corticosteroid-insensitive phenotype. Am. J. Respir. Cell Mol. Biol. 27, 361-367.

He, B., Cruz-Topete, D., Oakley, R.H., Xiao, X., Cidlowski, J.A., 2016. Human glucocorticoid receptor beta regulates gluconeogenesis and inflammation in mouse liver. Mol. Cell Biol. 36, 714-730.

Hecht, K., Carlstedt-Duke, J., Stierna, P., Gustafsson, J., Bronnegard, M., Wikstrom, A.C., 1997. Evidence that the beta-isoform of the human glucocorticoid receptor does not act as a physiologically significant repressor. J. Biol. Chem. 272, 26659-26664.

Heitzer, M.D., Wolf, I.M., Sanchez, E.R., Witchel, S.F., DeFranco, D.B., 2007. Glucocorticoid receptor physiology. Rev. Endocr. Metab. Disord. 8, 321-330.

Hinds, T.D., Ramakrishnan, S., Cash, H.A., Stechschulte, L.A., Heinrich, G., Najjar, S.M., Sanchez, E.R., 2010. Discovery of glucocorticoid receptor- in mice with a role in metabolism. Mol. Endocrinol. 24, 1715-1727.

Hollenberg, S.M., Weinberger, C., Ong, E.S., Cerelli, G., Oro, A., Lebo, R. Thompson, E.B., Rosenfeld, M.G., Evans, R.M., 1985. Primary structure and expression of a functional human glucocorticoid receptor cDNA. Nature 318, 635-641.

Kelly, A., Bowen, H., Jee, Y., Mahfiche, N., Soh, C., Lee, T., Hawrylowicz, C., Lavender, P., 2008. The glucocorticoid receptor $\beta$ isoform can mediate transcriptional repression by recruiting histone deacetylases. J. Allergy Clin. Immunol. 121, 203-208 e1.

Kim, S.-H., Kim, D.-H., Lavender, P., Seo, J.-H., Kim, Y.-S., Park, J.-S., Kwak, S.-J., Jee, Y.K., 2009. Repression of TNF- $\alpha$-induced IL-8 expression by the glucocorticoid receptor- $\beta$ involves inhibition of histone H4 acetylation. Exp. Mol. Med. 41, 297.

Kino, T., Manoli, I., Kelkar, S., Wang, Y., Su, Y.A., Chrousos, G.P., 2009a. Glucocorticoid receptor (GR) $\beta$ has intrinsic, GR $\alpha$-independent transcriptional activity. Biochem. Biophys. Res. Commun. 381, 671-675.

Kino, T., Su, Y.A., Chrousos, G.P., 2009b. Human glucocorticoid receptor isoform B: recent understanding of its potential implications in physiology and pathophysiology. Cell. Mol. Life Sci. 66, 3435-3448.

Koga, Y., Matsuzaki, A., Suminoe, A., Hattori, H., Kanemitsu, S., Hara, T., 2005. Differential mRNA expression of glucocorticoid receptor $\alpha$ and $\beta$ is associated with glucocorticoid sensitivity of acute lymphoblastic leukemia in children. Pediatr. Blood Cancer 45, 121-127.

Leung, D.Y., Hamid, O. Vottero, A., Szefler, S.J., Surs, W., Minshall, E., Chrousos, G.P., Klemm, D.J., 1997. Association of glucocorticoid insensitivity with increased expression of glucocorticoid receptor beta. J. Exp. Med. 186, 1567-1574.

Lewis-Tuffin, L.J., Jewell, C.M., Bienstock, R.J., Collins, J.B., Cidlowski, J.A., 2007. Human glucocorticoid receptor binds RU-486 and is transcriptionally active. Mol. Cell. Biol. 27, 2266-2282.

Li, L.b., 2006. Divergent expression and function of glucocorticoid receptor in human monocytes and T cells. J. Leukoc. Biol. 79, 818-827.

Longui, C.A., Vottero, A., Adamson, P.C., Cole, D.E., Kino, T., Monte, O., Chrousos, G.P. 2000. Low glucocorticoid receptor alpha/beta ratio in T-cell lymphoblastic leukemia. Horm. Metab. Res. 32, 401-406.

Nicolaides, N.C., Galata, Z., Kino, T., Chrousos, G.P., Charmandari, E., 2010. The human glucocorticoid receptor: molecular basis of biologic function. Steroids 75 , $1-12$.

Oakley, R.H., Sar, M., Cidlowski, J.A., 1996. The human glucocorticoid receptor beta isoform. Expression, biochemical properties, and putative function. J. Biol. Chem. 271, 9550-9559.

Oakley, R.H., Webster, J.C., Sar, M., Parker Jr., C.R., Cidlowski, J.A., 1997. Expression and subcellular distribution of the beta-isoform of the human glucocorticoid receptor. Endocrinology 138, 5028-5038.

Oakley, R.H., Jewell, C.M., Yudt, M.R., Bofetiado, D.M., Cidlowski, J.A., 1999. The dominant negative activity of the human glucocorticoid receptor beta isoform. Specificity and mechanisms of action. J. Biol. Chem. 274, 27857-27866.

Orii, F., Ashida, T., Nomura, M., Maemoto, A., Fujiki, T., Ayabe, T., Imai, S., Saitoh, Y., Kohgo, Y., 2002. Quantitative analysis for human glucocorticoid receptor alpha/ beta mRNA in IBD. Biochem. Biophys. Res. Commun. 296, 1286-1294.

Otto, C., Reichardt, H.M., Schutz, G., 1997. Absence of glucocorticoid receptor-beta in mice. J. Biol. Chem. 272, 26665-26668.

Pujols, L., Mullol, J., Roca-Ferrer, J., Torrego, A., Xaubet, A., Cidlowski, J.A., Picado, C. 2002. Expression of glucocorticoid receptor alpha- and beta-isoforms in human cells and tissues. Am. J. Physiol. Cell Physiol. 283, C1324-C1331.

Rauwerda, H., de Jong, M., de Leeuw, W.C., Spaink, H.P., Breit, T.M., 2010. Integrating heterogeneous sequence information for transcriptome-wide microarray design; a Zebrafish example. BMC Res. Notes 3, 192.

Revollo, J.R., Cidlowski, J.A., 2009. Mechanisms generating diversity in glucocorticoid receptor signaling. Ann. N. Y. Acad. Sci. 1179, 167-178.

Ruben, S.M., Dillon, P.J., Schreck, R., Henkel, T., Chen, C.H., Maher, M., Baeuerle, P.A., Rosen, C.A., 1991. Isolation of a rel-related human cDNA that potentially encodes the 65-kD subunit of NF-kappa B. Science 254, 11.

Sapolsky, R.M., Romero, L.M., Munck, A.U., 2000. How do glucocorticoids influence stress responses? Integrating permissive, suppressive, stimulatory, and preparative actions. Endocr. Rev. 21, 55-89.

Schaaf, M.J., Champagne, D., van Laanen, I.H., van Wijk, D.C., Meijer, A.H. Meijer, O.C., Spaink, H.P., Richardson, M.K., 2008. Discovery of a functional glucocorticoid receptor beta-isoform in zebrafish. Endocrinology 149 1591-1599.

Schaaf, M.J., Chatzopoulou, A., Spaink, H.P., 2009. The zebrafish as a model system for glucocorticoid receptor research. Comp. Biochem. Physiol. A Mol. Integr. Physiol. 153, 75-82.

Scheer, N., Groth, A., Hans, S, Campos-Ortega, J.A., 2001. An instructive function for Notch in promoting gliogenesis in the zebrafish retina. Development 128 , 1099-1107.

Schoneveld, O.J., Gaemers, I.C., Lamers, W.H., 2004. Mechanisms of glucocorticoid signalling. Biochim. Biophys. Acta 1680, 114-128.

Shahidi, H., Vottero, A., Stratakis, C.A., Taymans, S.E., Karl, M., Longui, C.A. Chrousos, G.P., Daughaday, W.H., Gregory, S.A., Plate, J.M., 1999. Imbalanced expression of the glucocorticoid receptor isoforms in cultured lymphocytes rom a patient with systemic glucocorticoid resistance and chronic lymphocytic leukemia. Biochem. Biophys. Res. Commun. 254, 559-565.

Sousa, A., Lane, S., Cidlowski, J., Staynov, D., Lee, T., 2000. Glucocorticoid resistance in asthma is associated with elevated in vivo expression of the glucocorticoid receptor $\beta$-isoform*. J. Allergy Clin. Immunol. 105, 943-950.

Stockhammer, O.W., Rauwerda, H., Wittink, F.R., Breit, T.M., Meijer, A.H., Spaink, H.P., 2010. Transcriptome analysis of Traf6 function in the innate immune response of zebrafish embryos. Mol. Immunol. 48, 179-190.

Strickland, I., Kisich, K., Hauk, P.J., Vottero, A., Chrousos, G.P., Klemm, D.J. Leung, D.Y., 2001. High constitutive glucocorticoid receptor beta in human neutrophils enables them to reduce their spontaneous rate of cell death in response to corticosteroids. J. Exp. Med. 193, 585-593.

Taniguchi, Y., Iwasaki, Y., Tsugita, M., Nishiyama, M., Taguchi, T., Okazaki, M. Nakayama, S., Kambayashi, M., Hashimoto, K., Terada, Y., 2010. Glucocorticoid receptor- and receptor- exert dominant negative effect on gene repression but not on gene induction. Endocrinology 151, 3204-3213.

van der Laan, S., Meijer, O.C., 2008. Pharmacology of glucocorticoids: beyond receptors. Eur. J. Pharmacol, 585, 483-491.

van der Vaart, M., Schaaf, M.J., 2009. Naturally occurring C-terminal splice variants of nuclear receptors. Nucl. Recept Signal 7, e007.

Yudt, M.R., Jewell, C.M., Bienstock, R.J., Cidlowski, J.A., 2003. Molecular origins for the dominant negative function of human glucocorticoid receptor beta. Mol. Cell. Biol. 23, 4319-4330.

Zhang, X., 2005. Regulation of glucocorticoid responsiveness in glaucomatous trabecular meshwork cells by glucocorticoid receptor. Investig. Ophthalmol. Vis. Sci. 46, 4607-4616.

Zhang, H., Ouyang, Q., Wen, Z.H., Fiocchi, C., Liu, W.P., Chen, D.Y., Li, F.Y., 2005. Significance of glucocorticoid receptor expression in colonic mucosal cells of patients with ulcerative colitis. World J. Gastroenterol. 11, 1775-1778.

Zhang, X., Ognibene, C., Clark, A., Yorio, T., 2007. Dexamethasone inhibition of trabecular meshwork cell phagocytosis and its modulation by glucocorticoid receptor $\beta$. Exp. Eye Res. 84, 275-284. 